\title{
Article \\ Influence of Nisin-Biogel at Subinhibitory Concentrations on Virulence Expression in Staphylococcus aureus Isolates from Diabetic Foot Infections
}

\author{
Carolina Jesus $(\mathbb{D}$, Rui Soares $(\mathbb{D}$, Eva Cunha $\mathbb{(}$, Miguel Grilo, Luís Tavares and Manuela Oliveira *(i)

\begin{abstract}
CIISA - Centro de Investigação Interdisciplinar em Sanidade Animal, Faculdade de Medicina Veterinária, Universidade de Lisboa, Avenida da Universidade Técnica, 1300-477 Lisboa, Portugal; carolinaojesus@gmail.com (C.J.); rmsoares@fmv.ulisboa.pt (R.S.); evacunha@fmv.ulisboa.pt (E.C.); miguelgrilo@fmv.ulisboa.pt (M.G.); ltavares@fmv.ulisboa.pt (L.T.)

* Correspondence: moliveira@fmv.ulisboa.pt
\end{abstract}

check for updates

Citation: Jesus, C.; Soares, R.; Cunha, E.; Grilo, M.; Tavares, L.; Oliveira, M. Influence of Nisin-Biogel at Subinhibitory Concentrations on Virulence Expression in Staphylococcus aureus Isolates from Diabetic Foot Infections. Antibiotics 2021, 10, 1501. https://doi.org/10.3390/ antibiotics10121501

Academic Editor:

Ágnes Pál-Sonnevend

Received: 7 November 2021

Accepted: 3 December 2021

Published: 7 December 2021

Publisher's Note: MDPI stays neutral with regard to jurisdictional claims in published maps and institutional affiliations.

Copyright: (c) 2021 by the authors. Licensee MDPI, Basel, Switzerland. This article is an open access article distributed under the terms and conditions of the Creative Commons Attribution (CC BY) license (https:// creativecommons.org/licenses/by/ $4.0 /)$.

\begin{abstract}
A new approach to diabetic foot infections (DFIs) has been investigated, using a nisin-biogel combining the antimicrobial peptide (AMP) nisin with the natural polysaccharide guar-gum. Since in in vivo conditions bacteria may be exposed to decreased antimicrobial concentrations, known as subinhibitory concentrations (sub-MICs), effects of nisin-biogel sub-MIC values corresponding to $1 / 2,1 / 4$ and $1 / 8$ of nisin's minimum inhibitory concentration (MIC) on virulence expression by six Staphylococcus aureus DFI isolates was evaluated by determining bacteria growth rate; expression of genes encoding for staphylococcal protein A $(s p A)$, coagulase (coa), clumping factor A (clfA), autolysin (atl), intracellular adhesin A (icaA), intracellular adhesin D (icaD), and the accessory gene regulator I (agrl); biofilm formation; Coa production; and SpA release. Nisin-biogel sub-MICs decreased bacterial growth in a strain- and dose-dependent manner, decreased agrI, atl and clfA expression, and increased $s p A, c o a, i c a A$ and $i c a D$ expression. Biofilm formation increased in the presence of nisin-biogel at $1 / 4$ and 1/8 MIC, whereas 1/2 MIC had no effect. Finally, nisin-biogel at sub-MICs did not affect coagulase production, but decreased SpA production in a dose-dependent manner. Results highlight the importance of optimizing nisin-biogel doses before proceeding to in vivo trials, to reduce the risk of virulence factor's up-regulation due to the presence of inappropriate antimicrobial concentrations.
\end{abstract}

Keywords: diabetic foot infections; Staphylococcus aureus; subinhibitory concentrations; virulencerelated genes; biofilm

\section{Introduction}

Diabetes mellitus (DM) is a lifelong metabolic disorder that affects approximately 537 million people worldwide [1]. The development of diabetic foot ulcers (DFUs) is a serious complication associated with the DM triad of neuropathy, vasculopathy and immunopathy [2]. The severe loss of skin protective barriers creates a chance for tissue colonization by opportunistic microorganisms, including Staphylococcus aureus. Diabetic foot infections (DFIs) usually become chronic and result in increased patient morbidity and mortality, the most common DM complication requiring hospitalization and often resulting in lower-extremity amputations [3].

S. aureus is a Gram-positive bacterium that expresses several regulatory and virulence factors, which contributes to its success as a human opportunistic pathogen [4]. In the first step of a staphylococcal infection, the adhesion phase, the production of several cell surface-associated factors occurs, including clumping factor A (ClfA), staphylococcal protein A (SpA), and coagulase (Coa) that facilitate tissue attachment and evasion of the host immune system [4,5]. Staphylococcal major autolysin (Atl) is also relevant for staphylococcal attachment to surfaces, also participating in bacterial cell wall degradation, lysis mediated biofilm development and secretion of cytoplasmic proteins [6-8]. 
The ability to form biofilms is considered a major staphylococcal pathogenic feature [9]. Biofilms are characterized by the growth of adherent bacterial populations inside a selfproduced matrix of extracellular polymeric substances, conferring this sessile mode of life survival advantages, including enhanced antimicrobial resistance. The intercellular adhesion (ica) locus, ica $A D B C$, is associated with cell-to-cell adhesion, being responsible for the biosynthesis of the biofilm exopolysaccharide intercellular adhesion (PIA) [10-13]. The coordination between S. aureus adhesion and detachment is regulated by Quorum Sensing (QS). The accessory gene regulator $(a g r)$ of S. aureus is a QS global transcriptional regulator, controlling virulence factors and biofilm expression in a time and population density-dependent manner $[10,14,15]$.

Another key factor for the success of $S$. aureus as a human pathogen is the ability to rapidly develop or acquire multiple antibiotic resistance determinants. Nowadays, the development and spread of pathogenic bacteria that are resistant to conventional antibiotics is a major public health concern, which makes it urgent to discover, develop, and implement new effective therapeutic strategies [16-20]. Antimicrobial peptides (AMPs) have been proposed as promising therapeutic candidates to inhibit bacterial growth which can be used synergistically with antibiotics [17]. One of the most studied AMPs is nisin, a lantibiotic produced by Lactococcus lactis which interacts with the bacterial cell wall precursor lipid II, inhibiting cell wall synthesis, and uses lipid II as a docking molecule for subsequent pore formation [21]. Nisin was first commercialized as a food preservative, being recognized as safe by the Food and Agriculture Organization/World Health Organization (FAO/WHO) $[17,22,23]$. In recent years, it started to be investigated in veterinary and pharmaceutical fields, including for the management of bacterial infections, as this polypeptide presents antimicrobial activity against a broad spectrum of Gram-positive bacteria [17]. Staphylococcus species have a remarkable susceptibility to nisin, which represent an advantage for nisin application towards skin infections, including DFIs, and the treatment of multiple drug resistant systemic infections [17,22].

As AMPs can be inactivated or degraded before achieving their target, different methods for AMPs delivery have been widely investigated, aiming at increasing their clinically efficacy. Natural polysaccharides have been considered promising drug delivery systems mainly due to their non-toxicity, sustainability, biodegradability, biocompatibility, abundance, availability, and cost-effectiveness [24]. Guar gum is a natural, uncharged, and water-soluble polysaccharide that has been largely used for targeted drug delivery, promoting a controlled drug release and availability $[25,26]$. Considering all the promising features of nisin and guar gum, a guar gum gel-based delivery system for nisin, nisin-biogel, has been developed by our research team as an alternative or complementary strategy to conventional antibiotics used in DFIs treatment [27]. Previous studies have shown that the nisin-biogel had inhibitory capacity towards S. aureus DFI isolates either in their planktonic and biofilm forms [27], could be applied in combination with conventional antibiotics and antiseptics to improve their efficacy [28,29], maintained its activity when stored at temperatures below $22{ }^{\circ} \mathrm{C}$ for 24 months [30], exhibited no significant levels of cytotoxicity on human keratinocyte cells [30] and was able to diffuse and keep its antimicrobial activity in a DFU collagen three-dimensional (3D) model established to mimic the DFU environment [29]. However, before proceeding to in vivo trials, the effect of drug therapeutic doses on virulence determinants expression by $S$. aureus must be addressed, as it may affect infection pathogenesis. Minimum inhibitory concentration (MIC) is defined as the lowest concentration of an antimicrobial that inhibits the growth of most of the target bacterial population, under controlled in vitro conditions [31]. However, in DFIs patients there is a poor diffusion of the antimicrobials that results from DM patient's compromised blood circulation and low perfusion due to angiopathy [31,32]. As such, in in vivo infections, bacteria may be exposed to a reduced effective concentration of antimicrobials, referred to as subinhibitory concentrations (sub-MICs), which can lead to a wide variety of physiological and morphological effects on bacteria and, consequently, affect infection pathogenesis [31,33]. Besides promoting bacterial resistance, sub-MICs of 
antimicrobials can modulate the virulence of $S$. aureus, by influencing gene expression, biofilm production and the QS system, which may impact the outcome of staphylococcal infections [31,33-36]. As such, the present study evaluated the effects of nisin-biogel subMICs on S. aureus DFI isolates growth rate, virulence-related genes expression, namely of agrI, spA, clfA, coa, atl, icaA and icaD, ability to form biofilm, Coa production and SpA release, aiming at confirming its suitability for in vivo administration.

\section{Results}

\subsection{Effect of Nisin-Biogel Sub-MICs on S. aureus DFI Isolates Growth Rate}

The effect of nisin-biogel sub-MICs on S. aureus DFI isolates A 5.2, A 6.3, B 1.1, B 14.2, $Z$ 1.1, and Z 5.2 growth rate is represented in Figure 1. Both in the presence or absence of nisin-biogel at sub-MICs, all S. aureus clinical isolates growth curves presented the typical sigmoidal pattern with the three phases of bacterial growth curves-the lag phase, the exponential phase, and the stationary phase. Nevertheless, different clinical isolates showed different growth rates, with isolate A 6.3 having the highest growth rate, and isolate A 5.2 having the lowest one. Nisin-biogel at sub-MICs slowed bacterial growth, delaying the beginning of the exponential growth phase. Nisin-biogel concentration equivalent to $1 / 8 \mathrm{MIC}$ was the one that promoted the lower change in bacterial growth, while the $1 / 2$ MIC was the concentration that promoted a higher change on the bacterial growth. For some $S$. aureus clinical isolates, including isolates Z 5.2, A 6.3, B 1.1 and Z 1.1, there was an increase in bacterial growth in the stationary phase in the presence of nisin-biogel at sub-MICs.

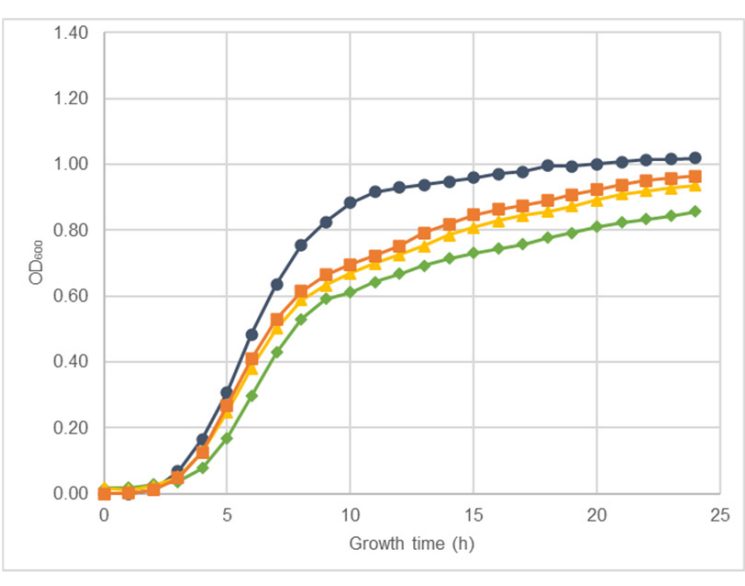

(a)

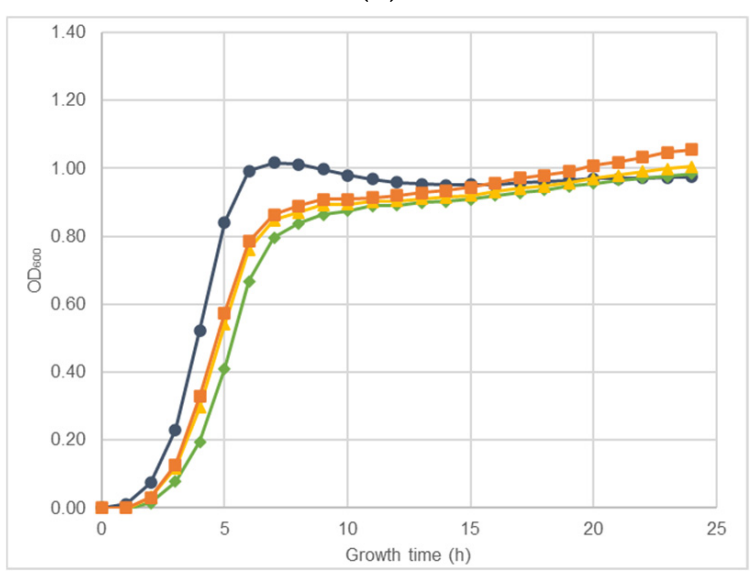

(c)

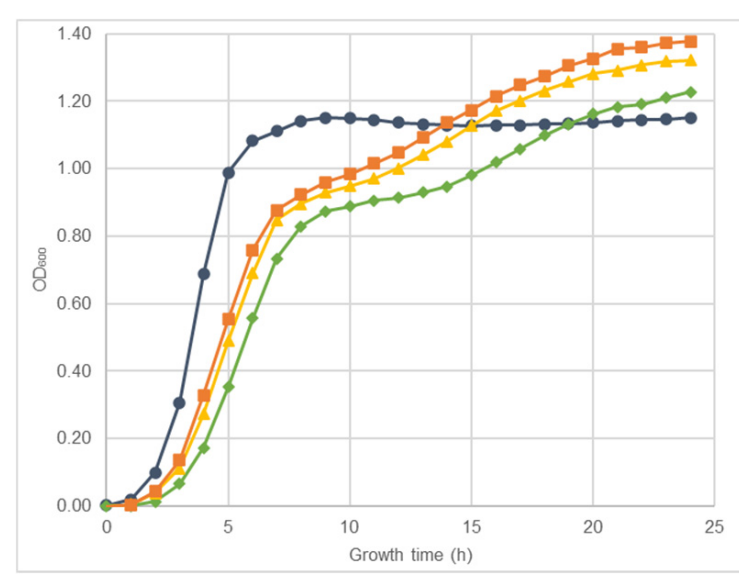

(b)

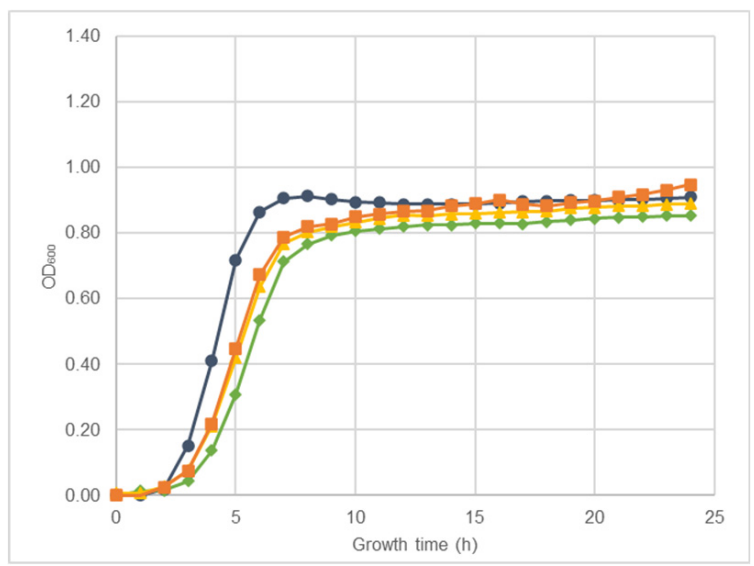

(d)

Figure 1. Cont. 


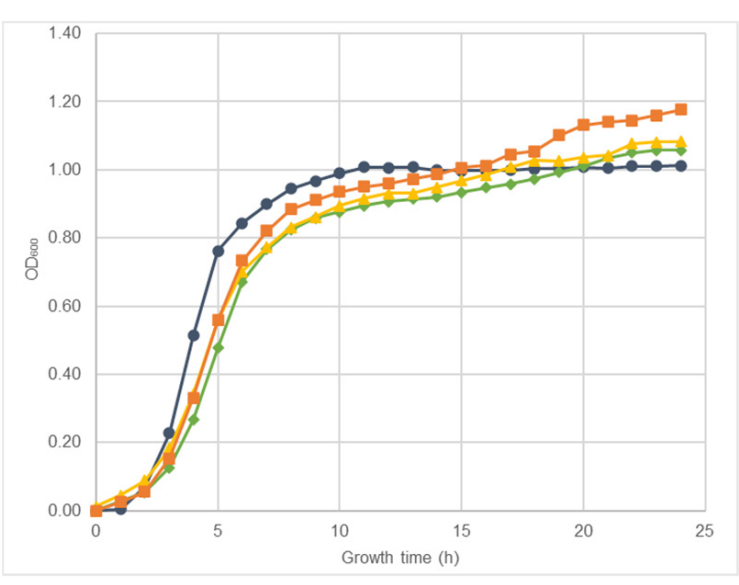

(e)

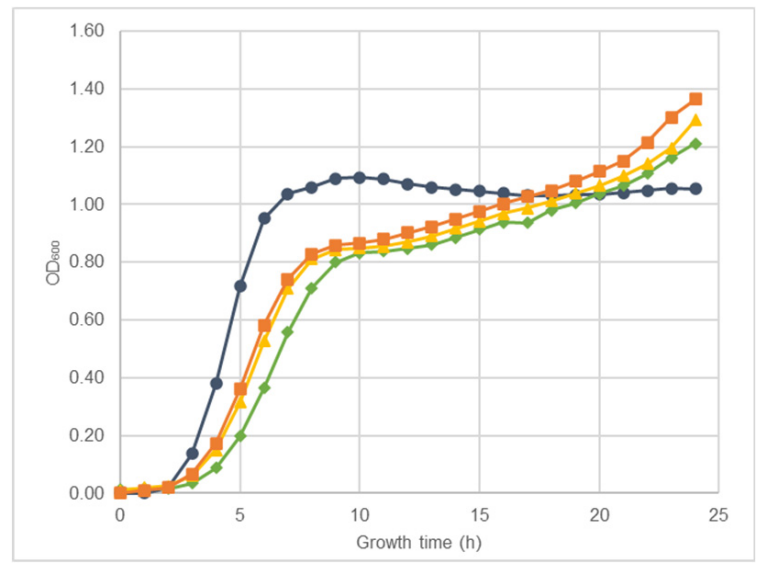

(f)

$$
\begin{aligned}
& \longrightarrow \text { Only isolate } \\
& \longrightarrow \text { Isolate + } 1 / 2 \text { MIC NB } \\
& \longrightarrow \text { Isolate + } 1 / 4 \text { MIC NB }
\end{aligned}
$$

Figure 1. Growth curves obtained for S. aureus clinical isolates during $24 \mathrm{~h}$ at $37^{\circ} \mathrm{C}$ with shaking $(150 \mathrm{rpm})$ in the absence or in the presence of different sub-MICs of nisin-biogel. Results are presented as mean values of three independent assays, reflecting bacterial growth for each $S$. aureus clinical isolate under the different conditions tested. (a): Strain ID A 5.2, isolated from a DFI aspirate $(\operatorname{agr} I+; s p A+;$ atl + ; clf $A+$; coa $+; i c a A+; i c a D+$; Biofilm production +; MSSA). (b): Strain ID A 6.3, isolated from a DFI aspirate (agrI +; spA +; atl +; clfA +;coa +; icaA +; icaD +; Biofilm production +; MSSA). (c): Strain ID B 1.1, isolated from a DFI biopsy (agrI +;spA +; atl +; clfA +; coa +;icaA +;icaD +; Biofilm production +; MRSA). (d): Strain ID B 14.2, isolated from a DFI biopsy (agrI +; sp + +; atl +; clf $A+; c o a+; i c a A+; i c a D+$; Biofilm production +; MRSA). (e): Strain ID Z 1.1, isolated from a DFI swab (agrI +; spA +; atl +; clf $A+; c o a+; i c a A+; i c a D+;$ Biofilm production +; MRSA). (f): Strain ID Z 5.2, isolated from a DFI swab (agrI +; spA +; atl +; clfA +; coa +; ica $A+; i c a D+$; Biofilm production +; MSSA). MIC: minimum inhibitory concentration. NB: nisin-biogel. $\mathrm{OD}_{600}:$ optical density at $600 \mathrm{~nm}$.

\subsection{S. aureus DFI Isolates Gene Expression Kinetics}

S. aureus clinical isolates virulence genes expression kinetics was accessed using RTqPCR assays. Figure 2a,b show that for agrI and atl, the highest expression levels were reached at 6 hours' incubation, while for $s p A$ and $c l f A$ it was at $4 \mathrm{~h}$. For coa, maximum expression levels were reached at $3 \mathrm{~h}$. Although the optical expression of the different genes occurred at different periods of bacterial growth, all revealed a considerable expression at $4 \mathrm{~h}^{\prime}$ incubation, which allowed to select this time point as the more adequate for further evaluation of the effects of nisin-biogel sub-MICs on $a g r I, s p A, c l f A$, atl and coa expression. Genes $i c a A$ and $i c a D$ reach their maximum expression levels at $48 \mathrm{~h}$ (Figure 3 ), which allowed to select this time point to icaA and icaD expression assays.

\subsection{Effect of Nisin-Biogel at Sub-MICs on Gene Expression by S. aureus DFI Isolates}

The effect of nisin-biogel and clindamycin at sub-MICs on virulence genes expression by S. aureus DFI isolates was investigated using RT-qPCR assays. As shown in Figure 4 and Table S1 (available as Supplementary Data), the effects depended on the virulence factor, on the $S$. aureus clinical isolate, and on the subinhibitory concentration under study. Overall, nisin-biogel and clindamycin at sub-MICs values significantly decreased the expression of agrI, with nisin-biogel at $1 / 2$ MIC being the one that reduced the expression of agrI the most, and $1 / 8 \mathrm{MIC}$ the one that least reduce agrI expression (Figure 4a). Nisin-biogel at sub-MICs increased the expression of $s p A$, while clindamycin at 1/2 MIC significantly decreased the expression of this gene (Figure $4 \mathrm{~b}$ ). For atl, nisin-biogel at sub-MICs significantly decreased its expression, with 1/2 MIC being the one that least decreased atl expression. Unlike nisin-biogel at sub-MICs, clindamycin at 1/2 MIC increased the expression of this gene (Figure 4c). Nisin-biogel at sub-MICs significantly decreased clfA expression, with 1/2 MIC 
being responsible for the highest increase in the expression of this gene. On the other hand, clindamycin at $1 / 2$ MIC significantly increased clf $A$ expression (Figure $4 \mathrm{~d}$ ). For coa, both nisin-biogel and clindamycin at sub-MICs increased gene expression and, regarding nisin-biogel, 1/2 MIC was the one that increased coa expression the most (Figure 4e). For ica $A$, nisin-biogel at $1 / 4$ and $1 / 8$ MIC slightly increased the expression of this gene, while at $1 / 2$ MIC slightly decreased icaA expression. Clindamycin at $1 / 2$ MIC decreased ica $A$ expression (Figure $4 \mathrm{f}$ ). Finally, for $i c a D$, nisin-biogel sub-MICs slightly increased gene expression, while clindamycin at $1 / 2$ MIC decreased its expression (Figure $4 \mathrm{~g}$ ).

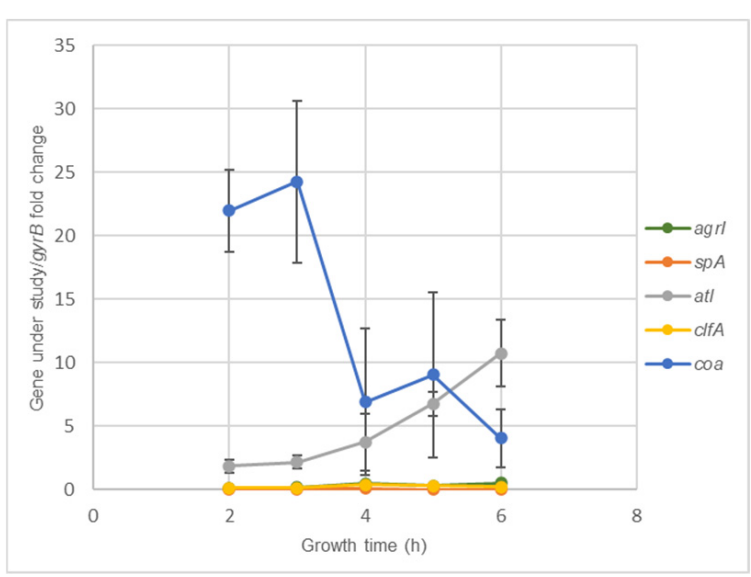

(a)

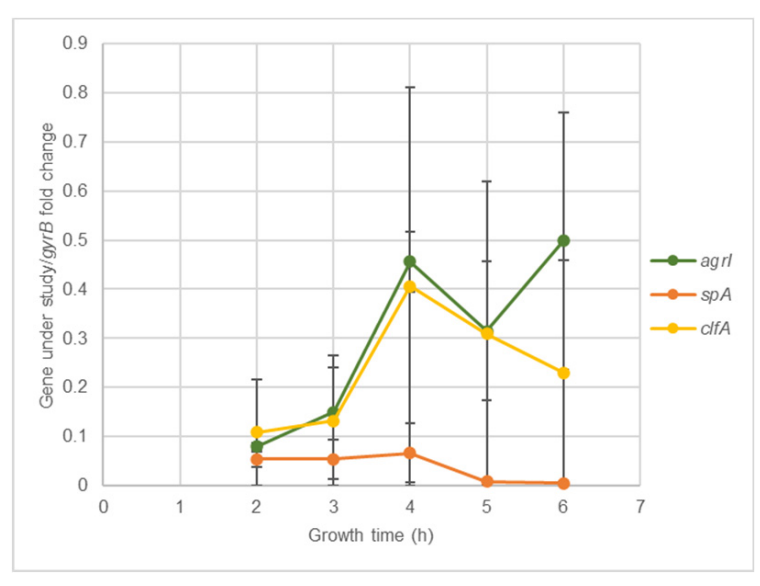

(b)

Figure 2. agrI, $s p A, c l f A$, atl and coa expression kinetics by $S$. aureus during a five hour growth period. Results are expressed as 'gene under study/gyrB' fold changes at 2,3,4,5 and $6 \mathrm{~h}$. Values are presented as means values \pm SD (isolates A 5.2 and $\mathrm{Z}$ 5.2). (b) corresponds to an amplification of part of (a), so the y axis has different scales in the two figures. agrI: accessory gene regulator I; $s p A$ : gene encoding staphylococcal protein A; atl: gene encoding autolysin; clfA: gene encoding clumping factor A; coa: gene encoding coagulase; gyrB: gene encoding gyrase B.

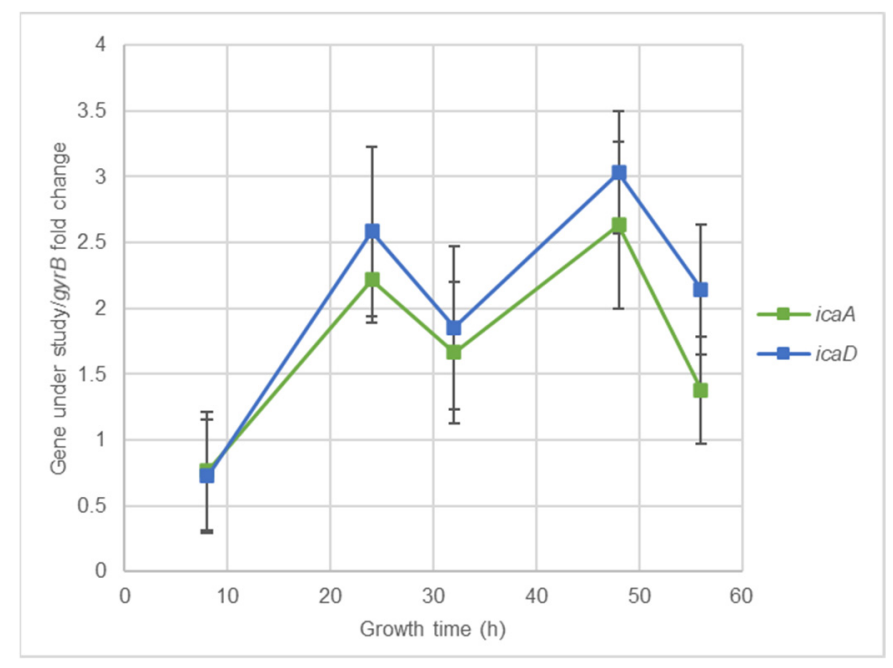

Figure 3. icaA and icaD expression kinetics for $48 \mathrm{~h}$. Results are expressed as 'gene under study/gyrB' fold changes at $8,24,32,48$, and $56 \mathrm{~h}$. Values are presented as means values $\pm \mathrm{SD}$ (isolates $\mathrm{A} 5.2$ and $Z$ 5.2). icaA: gene encoding intracellular adhesin A; icaD: gene encoding intracellular adhesin $D ;$ gyrB: gene encoding gyrase $\mathrm{B}$. 


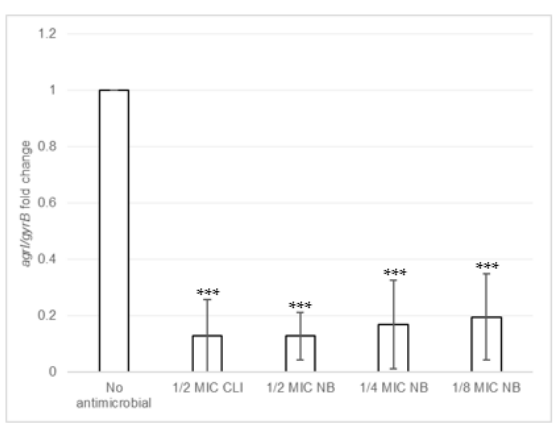

(a)

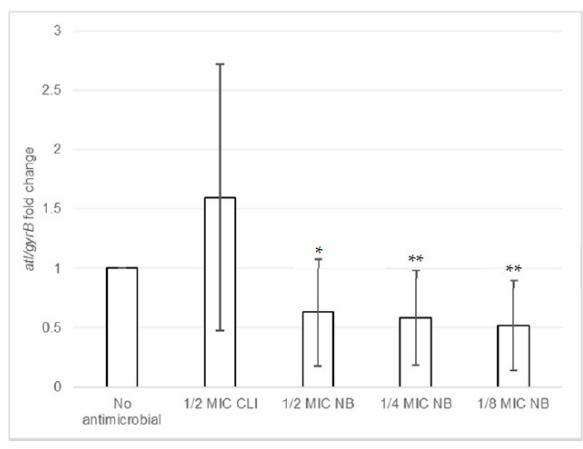

(c)

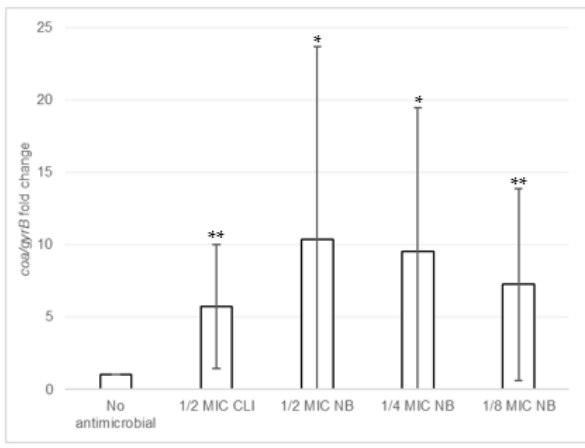

(e)

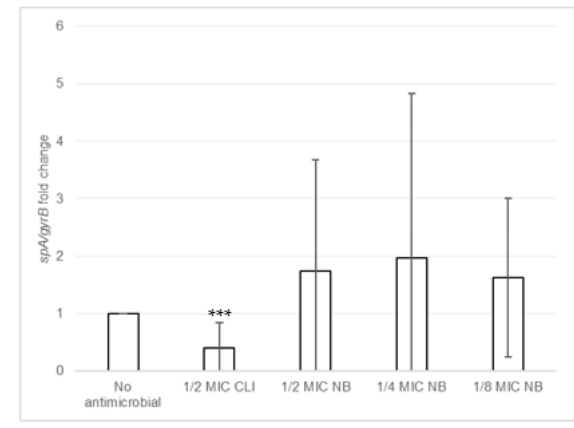

(b)

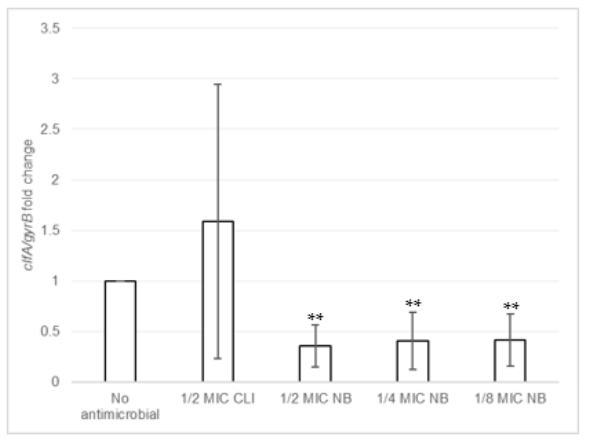

(d)

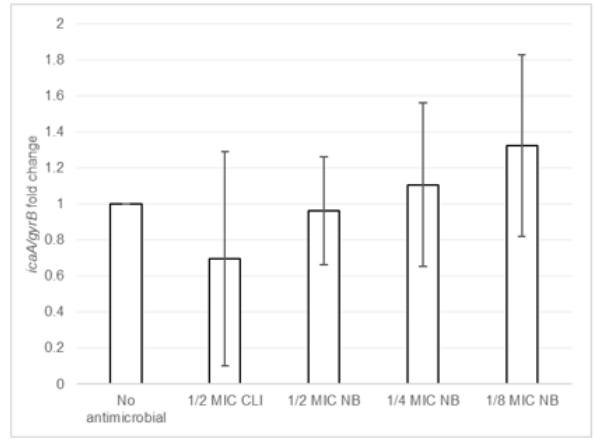

(f)

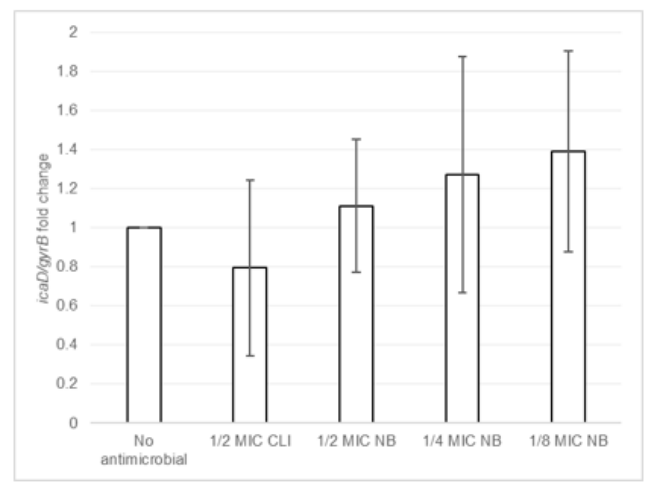

(g)

Figure 4. (a-g): Effects of nisin-biogel at 1/2 MIC, 1/4 MIC and 1/8 MIC and clindamycin at 1/2 MIC on agrI, spA, atl, clfA, coa, icaA and icaD mRNA expression, respectively. Results are expressed as n-fold differences in the 'gene under study/gyr $B^{\prime}$ ratio in the presence of the different conditions described above relative to 'gene under study/gyr $B$ ' ration in the growth control (no antimicrobial). Values are means $\pm \mathrm{SD}$ (two repeated different experiments). Asterisks indicate statistically significant differences between treatments and control $\left.{ }^{*}=p<0.05 ;{ }^{* *}=p<0.01 ;{ }^{* * *}=p<0.001\right)$. NB: nisin-biogel; CLI: clindamycin; MIC: minimum inhibitory concentration. agrI: accessory gene regulator I; $s p A$ : gene encoding staphylococcal protein A; atl: gene encoding autolysin; $c l f A$ : gene encoding clumping factor A; coa: gene encoding coagulase; $i c a A$ : gene encoding intracellular adhesin A; icaD: gene encoding intracellular adhesin D; gyrB: gene encoding gyrase B. 


\subsection{Effect of Nisin-Biogel Sub-MICs on the Ability of S. aureus DFI Isolates to Form Biofilm}

Biofilm formation by S. aureus DFI isolates in the presence of nisin-biogel and clindamycin at sub-MICs was determined using a microtiter assay. Results shown in Table S2 (available as Supplementary Data) demonstrate that different $S$. aureus clinical isolates have different responses to nisin-biogel and clindamycin at sub-MICs. In Figure 5 it is possible to observe that, overall, nisin-biogel at $1 / 4$ and clindamycin at $1 / 2 \mathrm{MIC}$ exhibit a trend to increase the ability of $S$. aureus isolates to form biofilm, and, in the presence of nisin-biogel at $1 / 8$ MIC, biofilm formation significantly increases. Oppositely, nisin-biogel at $1 / 2$ MIC had no effect in the ability of $S$. aureus clinical isolates to form biofilm.

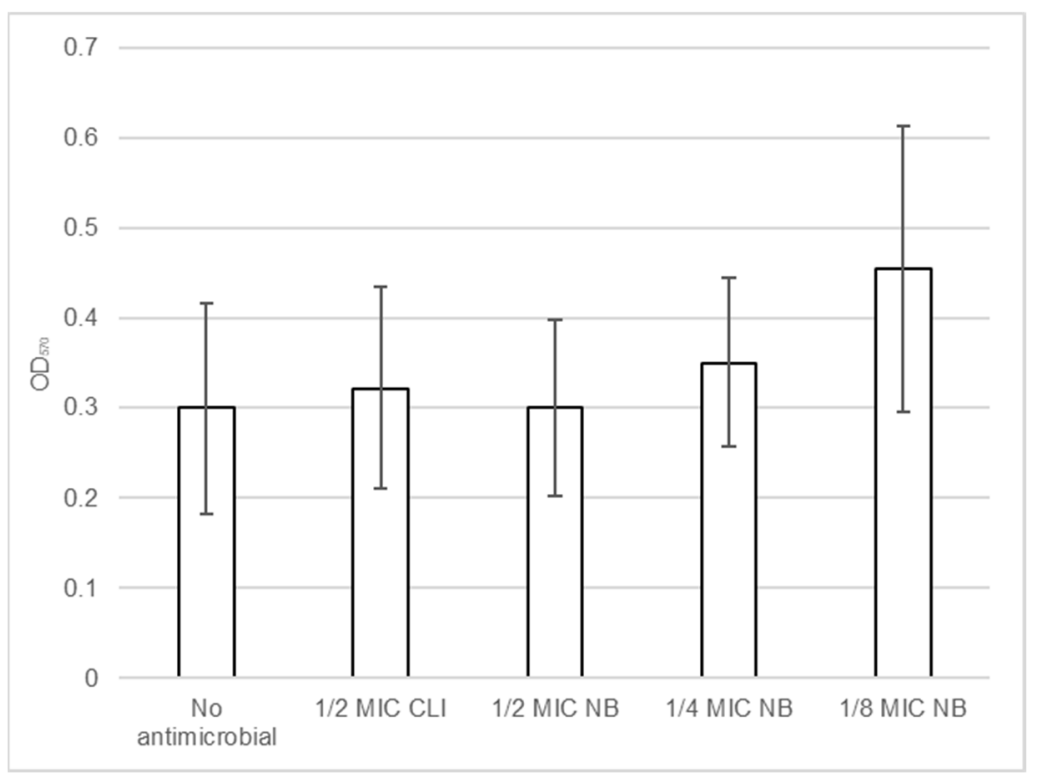

Figure 5. Effects of nisin-biogel at 1/2 MIC, 1/4 MIC and 1/8 MIC and clindamycin at 1/2 MIC on the ability of $S$. aureus DFI isolates to form biofilm. Values are presented as means \pm SD (three repeated different experiments). Asterisks indicate statistically significant differences between treatments and control. NB: nisin-biogel; CLI: clindamycin; MIC: minimum inhibitory concentration. $\mathrm{OD}_{570}$ : optical density at $570 \mathrm{~nm}$.

\subsection{Effect of Nisin-Biogel Sub-MICs on Coa Production by S. aureus DFI Isolates}

Coagulase test was used to monitor coagulase production by S. aureus clinical isolates in presence and absence of nisin-biogel and clindamycin at sub-MICs. Results were considered valid if the control plasma showed no signs of clotting in all assays.

Different clinical isolates showed different coagulase production ability over $4 \mathrm{~h}$ and after $24 \mathrm{~h}$ of incubation in the presence or absence of nisin-biogel and clindamycin at subMICs, as shown in Tables S3 and S4 (available as Supplementary Data). Besides depending on the $S$. aureus clinical isolate, the effects of antimicrobials sub-MICs on coagulation varied according to the bacterial growth period. During the first $4 \mathrm{~h}$, in which results were monitored on an hourly basis, clotting in the absence of nisin-biogel was higher than or equal to the one obtained in the presence of nisin-biogel at sub-MICs. After $24 \mathrm{~h}$ incubation, most clinical isolates showed the same degree of clotting in the presence or absence of nisin-biogel. Regarding the effect of clindamycin at $1 / 2$ MIC, for isolates A 5.2, A 6.3, and $Z 5.2$ there was no signs of coagulation in the presence of the antibiotic, whereas for isolates B 1.1, B 14.2 and Z 1.1, clotting degree was equal or higher than the one obtained in the absence of clindamycin at $1 / 2$ MIC.

\subsection{Effect of Nisin-Biogel Sub-MICs on SpA Release by S. aureus DFI Isolates}

The effect of nisin-biogel and clindamycin at sub-MICs on SpA release by S. aureus DFI isolates was investigated using Protein A ELISA Kit. Results shown in Table S5 (available 
as Supplementary Data) demonstrate that different $S$. aureus clinical isolates have different responses regarding SpA release in the presence of antimicrobials sub-MICs. Figure 6 shows the overall effects of nisin-biogel and clindamycin at sub-MICs on the release of SpA by $S$. aureus DFI isolates. Nisin-biogel at $1 / 2$ significantly decreased the release of SpA, and the other conditions under study exhibited a trend to decrease SpA release by S. aureus clinical isolates.

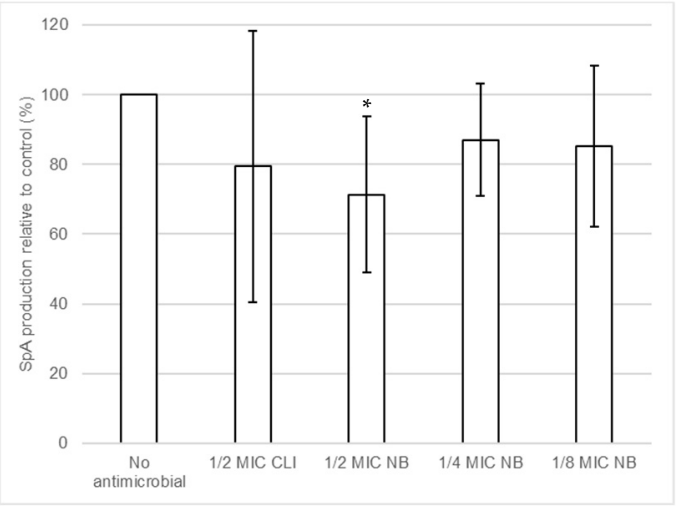

Figure 6. Effects of nisin-biogel at 1/2 MIC, 1/4 MIC and 1/8 MIC and clindamycin at 1/2 MIC on SpA production by $S$. aureus DFI isolates. Results are the ratios of the amount of $\mathrm{SpA}(\mathrm{pg} / \mathrm{mL})$ in the bacterial supernatants incubated with nisin-biogel and clindamycin to the mean amount of SpA $(\mathrm{pg} / \mathrm{mL})$ incubated without antimicrobials and are expressed as supernatants. Values are presented as mean values $\pm \mathrm{SD}$. Asterisks indicate statistically significant differences between treatments and control $(*=p<0.05)$. NB: nisin-biogel; CLI: clindamycin; MIC: minimum inhibitory concentration. SpA: staphylococcal protein A.

\section{Discussion}

Diabetes mellitus (DM) is one of the most disseminated chronic diseases worldwide. The last International Diabetes Federation (IDF) Atlas states that, in 2021, 537 million adults aged over 20 years were living with diabetes worldwide. In Portugal, there were over 990 million cases of diabetes registered this year, with the cost associated to each diabetic patient being estimated to be approximately 2.990 euros (https: / diabetesatlas.org/data/ en/country/159/pt.html, accessed on 27 November 2021), proving that diabetes represents a significant health burden in our country [37].

A frequent and most devastating consequence of diabetes is the development of diabetic foot ulcers (DFU), which in about $50 \%$ of the cases become infected, developing to diabetic foot infections (DFI) [38]. Besides the conventional therapeutic protocols available for DFI treatment (e.g., debridement, wound healing agents, surgery and antibiotic therapy), several advanced therapeutics are also available, including bacteriophage therapy, negativepressure wound therapy, hyperbaric oxygen therapy, stem cell therapy and off-loading [38]. Antimicrobial peptides are also a promising approach for DFI treatment; however, as observed for conventional antibiotics, angiopathy and low perfusion associated with DFU pathogenesis may prevent antimicrobials to reach the infected DFUs at effective concentration, leading to the presence of sub-MICs at the site of infection, which may impair treatment success [31,32].

The presence of antimicrobials sub-MICs can have several effects on bacteria, including the inhibition of bacterial growth $[39,40]$ and therefore on infection progression [35,39]. As such, the effects of nisin-biogel at sub-MICs on bacterial growth were assessed. Previously, Field et al. [17] showed that nisin at sublethal concentrations slightly increased the lag period of $S$. aureus growth curve, which supports the results from this study, as the nisinbiogel sub-MICs values tested caused a reduction on $S$. aureus DFI isolates growth by increasing the lag phase. This reduction occurred in a dose-dependent manner, with the nisin-biogel at $1 / 2$ MIC being the concentration that decreased bacterial growth the most, whereas 1/8 MIC was the one that least affected bacterial growth. In the stationary growth 
phase, the S. aureus clinical isolates Z 5.2, A 6.3, B 1.1 and Z 1.1 seem capable of adapting to the presence of nisin-biogel at sub-MICs, presenting an increase in growth rate.

S. aureus expresses a multitude of virulence factors in a coordinated manner, and many of them are under the control of the agr quorum sensing system. The agr gene positively controls the expression of many exotoxins, mainly produced after the end of the exponential growth phase, allowing bacteria to spread from the colonization sites to deeper tissues, and negatively controls the transcription of some cell wall-associated proteins, mainly synthesized during exponential growth [41]. According to our results, agrI expression levels by the $S$. aureus isolates tested only started to be relevant after $4 \mathrm{~h}$, a period during which bacterial adherence to the host tissues already occurred in vivo. At this time point, the cell-surface proteins start to be down-regulated, whereas the virulence genes associated with bacterial dissemination and biofilm formation start to be up-regulated $[4,42,43]$. Peng et al. [44] showed that agr activity is required for post-exponential phase expression of various secreted proteins, which supports the fact that in the present study agr mRNA expression has its peak at $6 \mathrm{~h}$.

SpA is a microbial surface protein that plays an important role in interfering with host defenses, inhibiting antibody-mediated phagocytosis. Staphylococcal extracellular protein, Coa, also contributes for the persistence of $S$. aureus in the host cell, by stimulating clotting formation in plasma, inhibiting host clearance mechanisms [45,46]. Both proteins are mainly expressed in the early stage of $S$. aureus growth, i.e., before 3-4 h. A study by Vandenesch et al. [47] suggested that $s p A$ mRNA is synthetized for a brief period in the beginning of the exponential phase and then is switched off. Moreover, according to Lebeau et al. [48], coa mRNA is mainly expressed at the early stages of $S$. aureus growth. Results from this study also showied that coa and $s p A$ mRNA are mostly expressed at the early exponential growth phase.

ClfA is also a staphylococcal surface protein that binds to $\mathrm{Fg}$, allowing bacteria to colonize traumatized tissue and, later, form biofilms [49]. clfA is mainly expressed after $4 \mathrm{~h}$ of bacterial growth, i.e., at the late exponential growth phase. Results by Josefsson et al. [50] show that clfA expression is higher at $6 \mathrm{~h}$ and remains high until $24 \mathrm{~h}$ of $S$. aureus growth, which is not entirely in line with what we obtained in the present study, suggesting that different $S$. aureus strains may have different $c l f A$ mRNA expression kinetics. Atl protein has a multitude of functions, including attachment, bacterial cell wall degradation, biofilm development and bacteriolytic activity [51]. In the present study, atl expression increased with $S$. aureus growth period, within a time frame of $6 \mathrm{~h}$, probably due to the increased growth rate over this time period. These results are in accordance with those by Oshida et al. [52] that also reported an increase in atl expression during the exponential growth phase.

One of the most relevant staphylococcal virulence factors is biofilm production, conferring bacteria a wide range of adaptive advantages that contribute to bacteria survival and persistence in the host [32]. Thus, icaA and icaD, involved in icaADBC-dependent biofilm formation, are mainly expressed latter during $S$. aureus growth. According to Atshan et al., 2013 , ica $A$ and icaD are up-regulated at $24 \mathrm{~h}$ of $S$. aureus growth and not at $48 \mathrm{~h}$ as observed in the present study, which suggests that ica mRNA expression kinetics may differ between S. aureus strains [53]. Furthermore, Patel et al. [54] evaluated gene expression during Staphylococcus epidermidis biofilm formation and, in accordance with the present study, the expression levels of $i c a A$ and $i c a D$ at $48 \mathrm{~h}$ were the highest ones. Although this study focused on S. aureus, S. epidermidis also produces biofilm in an icaADBC-dependent manner, allowing to suggest that the time frame required for the expression of ica $A$ and icaD may be identical in both species.

Several studies have shown that the use of antimicrobials at sub-MICs modulates virulence gene expression and, consequently, influences bacterial pathogenicity [21,39]. Determining the effects of antimicrobials sub-MICs on virulence genes expression may provide important information for the rational use of antimicrobials in clinical practice [39]. One of the antibiotics currently applied as a DFIs alternative treatment is clindamycin, used 
in this study as a control to compare the effects of nisin-biogel at sub-MICs on S. aureus gene expression [21,55].

Subinhibitory levels of nisin-biogel decreased the expression of the regulatory gene agrI in a dose-dependent manner, which could lead to changes in the virulence modulation and positively affect infection treatment $[10,14,15]$. Regarding $s p A$ and coa, nisin-biogel at sub-MICs exhibited a trend to increase the expression of these genes, which can negatively affect infection treatment, as both SpA and Coa contribute for bacterial evasion from the host immune system [4,5]. Nisin-biogel at sub-MICs significantly decrease the expression of atl and clfA, possibly reducing $S$. aureus pathogenic potential. These results are in accordance with those by Zhao et al. [56], which stated that the exposure of $S$. aureus for $1 \mathrm{~h}$ to a nisin concentration equivalent to $1 / 2$ MIC lead to a down-regulation of atl and clfA.

Concerning ica $A$ and $i c a D$, involved in biofilm formation, the nisin-biogel at subinhibitory concentrations slightly increased their expression, which can contribute for an increase in biofilm formation, hindering infection treatment. Moreover, the lower the concentration of nisin-biogel, a higher increase of icaA and icaD mRNA levels was observed, which reinforces the importance of defining the optimum dosage of antimicrobials to be applied to the treatment of bacterial infections.

The effects of subinhibitory concentrations on bacterial biofilm formation were also investigated. Biofilms play a major role in the pathogenesis of S. aureus, and are present in 60 to $100 \%$ of chronic wounds, including DFUs [57]. Several studies have shown that subMICs of some antimicrobials can affect bacterial biofilm formation in vitro, which may have clinical importance [58,59]. Angelopoulou et al. [60] observed that nisin at 1/2,1/4 and $1 / 8$ MIC significantly increased biofilm formation by $S$. aureus, with the concentration of $1 / 8$ MIC also being the one that most influenced biofilm formation, as observed in this study. When exposed to nisin-biogel at $1 / 4$ and $1 / 8$ MIC values, the ability of $S$. aureus clinical isolates to form biofilm increased in a dose-dependent manner, while 1/2 MIC had no effect on biofilm formation. Moreover, the lower the concentration of nisin-biogel, the higher the increase in biofilm formation, which is mostly consistent with the effect on the expression of $i c a A$ and icaD. Moreover, as stated by other authors, the increase of biofilm formation may be due to the fact that sublethal concentrations of antimicrobials are cell stressors, which can enhance the production of biofilm matrix polymers $[59,61]$. However, Andre et al. [58] reported that subinhibitory concentrations of nisin promoted a reduction in biofilm formation, which suggests that different strains may present different responses regarding biofilm formation in the presence of sub-MICs of this antimicrobial peptide.

Alterations in the virulence determinants mRNA levels in the presence of subinhibitory levels of antimicrobials do not always result in changes in protein synthesis or functional activity $[62,63]$. According to our results, the increase in quantification of $s p A$ and coa mRNA in the presence of nisin-biogel at sub-MICs are not directly associated with an increase in SpA production or Coa activity, respectively. In fact, there was an unexpected significant increase of coa expression in the presence of subinhibitory levels of nisin-biogel. When accessing coagulase production, results were different, as most of the clinical isolates showed a similar coagulase activity in the presence of nisin-biogel at sub-MICs. Thus, our findings suggest that coa expression increase that occurs in the presence of nisin-biogel at sub-MICs may be associated with an increase in mRNA stabilization, as previously suggested by Blickwede et al. [64] regarding clindamycin influence on coa stability. On another end, SpA protein levels exhibited a trend to decrease in the presence of nisin-biogel at sub-MICs, which is partly not consistent with what happened to SpA mRNA levels. Actually, in the presence of nisin-biogel at sub-MICs levels, S. aureus DFI isolates increased SpA mRNA levels, which seems to suggest that the inhibition of virulence expression by nisin-biogel is primarily due to the blockage of protein translation at the ribosome, rather than the inhibition of virulence genes transcription. 


\section{Materials and Methods}

\subsection{Bacterial Strains}

S. aureus isolates used in the present study were previously obtained from patients with clinically infected DFUs using biopsies (isolates with a B in their identification code), swabs (isolates with a $\mathrm{Z}$ in their identification code) or aspirates (isolates with an $\mathrm{A}$ in their identification code), according to the current clinical guidelines [65]. The isolates were virulence and antimicrobial resistance profiles were previsouly analyzed by Polymerase Chain Reaction (PCR), including their biofilm-forming ability, and their clonal profile was previously determined by Pulse Field Gel Electrophoresis (PFGE) and Multilocus Sequence Type (MLST) [66]. S. aureus isolates A 5.2, A 6.3, B 1.1, B 14.2, Z 1.1 and Z 5.2 were selected for this study due to their virulence traits, which includes the presence of genes encoding for staphylococcal protein A $(s p A)$, autolysin $(a t l)$, clumping factor A $(c l f A)$, coagulase (coa), intracellular adhesin A (icaA), intracellular adhesin $\mathrm{D}(\mathrm{icaD})$ and the accessory regulator gene I (agrI), and to their capacity to produce biofilms. Moreover, isolates B 14.2, B 1.1 and Z 1.1 are methicillin-resistant S. aureus (MRSA), whereas isolates A 5.2, A 6.3 and Z 5.2 are methicillin-susceptible $S$. aureus (MSSA) $[38,66]$. The MICs of nisin-biogel and clindamycin for the $S$. aureus clinical isolates were previously determined, being, in average, of $22.5 \mu \mathrm{g} / \mathrm{mL}$ and $0.033 \mu \mathrm{g} / \mathrm{mL}$, respectively [27,67].

\subsection{Antimicrobial Solutions}

A stock solution of nisin $(1000 \mu \mathrm{g} / \mathrm{mL})$ was obtained by dissolving $1 \mathrm{~g}$ of nisin powder (2.5\% purity, $1000 \mathrm{IU} / \mathrm{mg}$, Sigma-Aldrich, St. Louis, MO, USA) in $25 \mathrm{~mL}$ of $\mathrm{HCl}(0.02 \mathrm{M})$ (Merck, Darmstadt, Germany). This solution was sterilized by filtration through a $0.22 \mu \mathrm{m}$ cellulose acetate membrane filter (Millipore, Burlington, MA, USA) and stored at $4{ }^{\circ} \mathrm{C}$ [27].

Brain Heart Infusion (BHI) or Trypticase Soy Broth (TSB) with guar-gum gel at $0.75 \%(w / v)$ were prepared by dissolving $3.75 \mathrm{~g}$ of guar-gum (Sigma-Aldrich, St. Louis, $\mathrm{MO}, \mathrm{USA}$ ) and $18.5 \mathrm{~g}$ of BHI powder (VWR Chemicals, Leuven, Belgium) or $15 \mathrm{~g}$ of TSB powder (VWR Chemicals, Leuven, Belgium), respectively, in $500 \mathrm{~mL}$ of sterile distilled water, and heat sterilized by autoclave [27].

Clindamycin is an alternative antibiotic currently used in clinical practice associated with mild DFIs and was used in the present study at $1 / 2$ MIC as a control for comparing the effects of nisin-biogel at sub-MICs on S. aureus DFI isolates virulence factors expression [28]. A stock solution of clindamycin was obtained by dissolving $6.6 \mathrm{mg}$ of clindamycin powder (Sigma-Aldrich, St. Louis, MO, USA) in $10 \mathrm{~mL}$ of sterile water and filtered using a $0.22 \mu \mathrm{m}$ cellulose acetate membrane filter. This stock solution was kept frozen at $-80^{\circ} \mathrm{C}$ and diluted with sterile water to the final concentration of $0.0165 \mu \mathrm{g} / \mathrm{mL}$ when required.

\subsection{Effects of Nisin-Biogel Sub-MICs on S. aureus DFI Isolates Growth Rate}

S. aureus DFI isolates were inoculated in a non-selective BHI agar medium (VWR Chemicals, Leuven, Belgium) at $37^{\circ} \mathrm{C}$ for $24 \mathrm{~h}$. After incubation, bacterial suspensions of $10^{8} \mathrm{CFU} / \mathrm{mL}$ were prepared directly from plate cultures using a $0.5 \mathrm{McF}$ arland standard in $\mathrm{NaCl}$ (Merck, Damstrants, Germany), and the bacterial suspensions were diluted in fresh $\mathrm{BHI}$ broth or in fresh BHI broth containing guar gum at $0.75 \%(w / v)$ to a final concentration of $10^{7} \mathrm{CFU} / \mathrm{mL}$. Afterwards, nisin was added to the fresh BHI broth with guar gum to obtain bacterial cultures with nisin-biogel at $1 / 2,1 / 4$ and $1 / 8$ MIC values. Then, the wells of a 96-well flat-bottomed polystyrene microtiter plates (Thermo Scientific, Waltham, MA, USA) were inoculated with $200 \mu \mathrm{L}$ of the negative controls (fresh BHI broth and fresh BHI broth with guar gum at $7.5 \mathrm{mg} / \mathrm{mL}$ ) and with $200 \mu \mathrm{L}$ of the different bacterial suspensions previously prepared, namely in fresh BHI broth, BHI broth with guar gum plus $1 / 2$ MIC of the nisin-biogel $(($ nisin $)=11.25 \mu \mathrm{g} / \mathrm{mL} ;($ guar gum $)=7.5 \mathrm{mg} / \mathrm{mL})$, BHI broth with guar gum plus 1 4 MIC of the nisin-biogel $($ (nisin $)=5.625 \mu \mathrm{g} / \mathrm{mL}$; (guar gum $)=7.5 \mathrm{mg} / \mathrm{mL})$ and BHI broth with guar gum plus 1/8 MIC of the nisin-biogel $(($ nisin $)=2.8175 \mu \mathrm{g} / \mathrm{mL}$; $($ guar gum $)=7.5 \mathrm{mg} / \mathrm{mL}$ ). 
Each different growth condition was evaluated in triplicate wells on three independent assays. During the $24 \mathrm{~h}$ of incubation at $37^{\circ} \mathrm{C}$ with shaking (150 rpm), optical density at $600 \mathrm{~nm}\left(\mathrm{OD}_{600}\right)$ for each well were obtained automatically every hour, using the FLUOstar OPTIMA (BMG LABTECH, Ortenberg, Germany) microplate reader. For each isolate, $\mathrm{OD}_{600}$ was calculated by subtracting the average $\mathrm{OD}_{600}$ of the three blank wells (fresh $\mathrm{BHI}$ broth or fresh BHI broth with guar gum at $7.5 \mathrm{mg} / \mathrm{mL}$ ) from the average of $\mathrm{OD}_{600}$ of the three replicates of the sample under evaluation. Final result corresponds to the average results of each independent assay replicates.

\subsection{S. aureus DFI Isolates Gene Expression Kinetics}

Isolates A 5.2 and Z 5.2 were inoculated in a non-selective BHI agar medium at $37^{\circ} \mathrm{C}$ for $24 \mathrm{~h}$. After incubation, bacterial suspensions of $10^{8} \mathrm{CFU} / \mathrm{mL}$ were prepared as described. Bacterial suspensions were diluted in fresh BHI broth to a final concentration of $10^{7} \mathrm{CFU} / \mathrm{mL}$ and grown at $37^{\circ} \mathrm{C}$ with gyratory shaking ( $\left.180 \mathrm{rpm}\right)$. For quantification of agrI, $s p A, c o a, c l f A$ and atl expression, aliquots were collected after 2, 3, 4, 5 and $6 \mathrm{~h}$ of incubation for subsequent stabilization of total RNA with RNAprotect ${ }^{\circledR}$ Bacteria Reagent (Qiagen, Hilden, Germany), enzymatic lysis of bacteria with Buffer TE containing lysostaphin (Sigma-Aldrich, St. Louis, MO, USA), RNA extraction using the Qiagen RNeasy Mini Kit (Qiagen, Hilden, Germany), and cDNA synthesis with random primers using a Promega Go ScriptTM Reverse Transcription System (Promega, Madison, WI, USA), according to manufacturer's instructions. Gene expression was analyzed by RT-qPCR [68], using the specific primers shown in Table S6 (available as Supplementary Data). RT-qPCR was performed in a 7300 Real Time PCR System (Applied Biosystems, Waltham, MA, USA) using the following conditions: an initial uracil-N-glycosylase gene (UNG) activation at $50{ }^{\circ} \mathrm{C}$ for $2 \mathrm{~min}$, followed by an initial DNA polymerase activation at $95^{\circ} \mathrm{C}$ for $10 \mathrm{~min}$, and 35 cycles consisting in melting at $95^{\circ} \mathrm{C}$ for $15 \mathrm{~s}$ and annealing/extending at $60^{\circ} \mathrm{C}$ for $1 \mathrm{~min}$. A set of dissociation steps was also performed, using the following conditions: $95^{\circ} \mathrm{C}$ for $15 \mathrm{~s}, 60^{\circ} \mathrm{C}$ for $1 \mathrm{~min}, 95^{\circ} \mathrm{C}$ for $15 \mathrm{~s}$, and $60^{\circ} \mathrm{C}$ for $15 \mathrm{~s}$. For icaA and icaD genes, aliquots were collected after $8,24,32,48$ and $56 \mathrm{~h}$ of incubation for subsequent stabilization of total RNA, enzymatic lysis of bacteria, RNA extraction, cDNA synthesis and analyses by RT-qPCR. The relative standard curve method was used to quantify gene transcription, using gyrase $B(g y r B)$ gene for normalization. An average \pm standard deviation of the fold change obtained for the isolates A 5.2 and Z 5.2 was considered for the determination of gene expression kinetics and, consequently, the best growth time for further investigate the effects of nisin-biogel at sub-MICs on virulence-related genes expression.

\subsection{Effects of Nisin-Biogel Sub-MICs on Gene Expression by S. aureus DFI Isolates}

Isolates A 5.2, A 6.3, B 1.1, B 14.2, Z1.1 and Z 5.2 were inoculated in a non-selective BHI agar medium at $37^{\circ} \mathrm{C}$ for $24 \mathrm{~h}$. After incubation, bacterial suspensions of $10^{8} \mathrm{CFU} / \mathrm{mL}$ were prepared as described. For each isolate, 5 different bacterial suspensions were prepared: in $\mathrm{BHI}$ broth, BHI broth plus clindamycin at $1 / 2$ MIC $($ (clindamycin $)=0.0165 \mu \mathrm{g} / \mathrm{mL})$, BHI broth with guargum at $7.5 \mathrm{mg} / \mathrm{mL}$ plus $1 / 2 \mathrm{MIC}$ of the nisin-biogel $(($ nisin $)=11.25 \mu \mathrm{g} / \mathrm{mL})$, BHI broth with guar-gum at $7.5 \mathrm{mg} / \mathrm{mL}$ plus 1/4 MIC of the nisin-biogel $(($ nisin $)=5.625 \mu \mathrm{g} / \mathrm{mL})$ and in BHI broth with guar-gum at $7.5 \mathrm{mg} / \mathrm{mL}$ plus $1 / 8 \mathrm{MIC}$ of the nisin-biogel $(($ nisin $)=2.8175 \mu \mathrm{g} / \mathrm{mL})$. All these suspensions were incubated at $37^{\circ} \mathrm{C}$ for $4 \mathrm{~h}$ to agrI, spa, atl, coa and clfa genes expression studies, and for $48 \mathrm{~h}$ to ica $A$ and icaD genes expression studies, with gyratory shaking (180 rpm).

After incubation, stabilization of total RNA, enzymatic lysis of bacteria, RNA extraction and cDNA synthesis were performed, and the resulting cDNA was used as a template for RT-qPCR using the specific primers shown in Table S1 (available as Supplementary Data), and the relative standard curve method was used to quantify transcription. Therefore, to determine the effects of nisin-biogel and clindamycin sub-MICs on virulence-related genes expression, the expression levels of the genes under investigation were expressed as fold change of the spa/gyrB, agrI/gyrB, coa/gyrB, clfa/gyrB, icaA/gyrB, icaD/gyrB and atl/gyrB 
ratios in the presence of antimicrobials (nisin-biogel or clindamycin) relative to the spa/gyr $B$, agrI/gyrB, coa/gyrB, clfa/gyrB, icaA/gyrB, icaD/gyrB and atl/gyrB ratios, respectively, of the growth control (no antimicrobial present). For each isolate and each incubation condition, two different and independent assays were performed.

\subsection{Effect of Nisin-Biogel Sub-MICs on the Ability of S. aureus DFI Isolates to Form Biofilm}

To test the influence of nisin-biogel sub-MICs on biofilm formation, a modified version of the protocol described by Santos et al. [27] was performed. Isolates A 5.2, A 6.3, B 1.1, B 14.2, Z 1.1 and Z 5.2 were inoculated in a non-selective BHI agar medium at $37^{\circ} \mathrm{C}$ for $24 \mathrm{~h}$. Then, three to five colonies were collected using a sterile loop, resuspended in $5 \mathrm{~mL}$ of TSB and incubated for $18 \mathrm{~h}$ at $37^{\circ} \mathrm{C}$. After incubation, the turbidity of bacterial suspension was adjusted to $0.5 \mathrm{McF}$ arland standard $\left(10^{8} \mathrm{CFU} / \mathrm{mL}\right)$, and 1:100 dilutions were made in TSB with $0.25 \%$ glucose, TSB with $0.25 \%$ glucose plus $1 / 2$ MIC of clindamycin $(($ clindamycin $)=0.0165 \mu \mathrm{g} / \mathrm{mL})$, TSB with guar-gum at $7.5 \mathrm{mg} / \mathrm{mL}$ and $0.25 \%$ glucose plus $1 / 2$ MIC of nisin-biogel ((nisin) $=11.25 \mu \mathrm{g} / \mathrm{mL})$, TSB with guar-gum at $7.5 \mathrm{mg} / \mathrm{mL}$ and $0.25 \%$ glucose plus $1 / 4 \mathrm{MIC}$ of nisin-biogel $(($ nisin $)=5.625 \mu \mathrm{g} / \mathrm{mL})$ and TSB with guar-gum at $7.5 \mathrm{mg} / \mathrm{mL}$ and $0.25 \%$ glucose plus $1 / 8 \mathrm{MIC}$ of nisin-biogel $(($ nisin $)=2.8175 \mu \mathrm{g} / \mathrm{mL})$.

Bacterial suspensions were transferred to a sterile 96-well polystyrene plate (200 $\mathrm{\mu L} /$ well) and incubated at $37^{\circ} \mathrm{C}$ for $48 \mathrm{~h}$. After incubation, the content of each well was removed, and the wells were carefully washed three times with $180 \mu \mathrm{L}$ of PBS, $\mathrm{pH}$ 7.0. Then, wells were filled with $200 \mu \mathrm{L}$ of PBS, $\mathrm{pH} 7.0$, and the microtiter plate was incubated in an ultrasound bath (Grant MXB14), at $50 \mathrm{~Hz}$ for $15 \mathrm{~min}$, in order to disperse the biofilm-based bacteria from the microtiter plate surface. Finally, the OD of the suspension from each well was measured at $570 \mathrm{~nm}$ using the FLUOstar OPTIMA microplate reader. Results were calculated by subtracting the average $\mathrm{OD}_{570}$ of the three replicas of the negative controls (TSB broth or TSB broth with guar gum at $7.5 \mathrm{mg} / \mathrm{mL}$ ) from the average of $\mathrm{OD}_{570}$ of the three wells of each sample. Final result corresponds to the average of the three independent assays.

\subsection{Effect of Nisin-Biogel Sub-MICs on Coa Production by S. aureus DFI Isolates}

Isolates A 5.2, A 6.3, B 1.1, B 14.2, Z 1.1 and Z 5.2 were inoculated in a non-selective BHI agar medium at $37^{\circ} \mathrm{C}$ for $24 \mathrm{~h}$. After, isolates were incubated in BHI broth, BHI broth plus clindamycin at $1 / 2 \mathrm{MIC}(($ clindamycin $)=0.0165 \mu \mathrm{g} / \mathrm{mL})$, BHI broth with guar-gum at $7.5 \mathrm{mg} / \mathrm{mL}$ plus nisin-biogel at $1 / 2 \mathrm{MIC}(($ nisin $)=11.25 \mu \mathrm{g} / \mathrm{mL})$, BHI broth with guar-gum at $7.5 \mathrm{mg} / \mathrm{mL}$ plus nisin-biogel at $1 / 4$ MIC $(($ nisin $)=5.625 \mu \mathrm{g} / \mathrm{mL})$ and BHI broth with guar-gum at $7.5 \mathrm{mg} / \mathrm{mL}$ plus nisin-biogel at $1 / 8 \mathrm{MIC}(($ nisin $)=2.8175 \mu \mathrm{g} / \mathrm{mL})$ for $24 \mathrm{~h}$ or for $4 \mathrm{~h}$ at $37^{\circ} \mathrm{C}$. Coagulase test was performed by adding $0.1 \mathrm{~mL}$ of each culture to $0.3 \mathrm{~mL}$ of rabbit plasma previously rehydrated with sterile water. After gentle mixing, suspensions were incubated at $37^{\circ} \mathrm{C}$ and examined every hour for $4 \mathrm{~h}$, and after $24 \mathrm{~h}$. Results were interpreted according to the scale proposed by Sperber \& Tatini, 1975, where negative means no evidence of fibrin formation, positive $1+$ means small unorganized clots, positive $2+$ means small organized clot, positive $3+$ means large organized clot, and positive $4+$ means that the entire content of tube coagulates and is not displaced when tube is inverted [69]. As negative controls, $0.1 \mathrm{~mL}$ of $\mathrm{BHI}$ broth or $0.1 \mathrm{~mL}$ of $\mathrm{BHI}$ broth with guar-gum at $7.5 \mathrm{mg} / \mathrm{mL}$ were added to $0.3 \mathrm{~mL}$ of rabbit plasma and incubated without bacteria in the same conditions.

\subsection{Effect of Nisin-Biogel Sub-MICs on SpA Release by S. aureus DFI Isolates}

Isolates A 5.2, A 6.3, B 1.1, B 14.2, Z 1.1 and Z 5.2 were inoculated in a non-selective $\mathrm{BHI}$ agar medium at $37^{\circ} \mathrm{C}$ for $24 \mathrm{~h}$. After, isolates were incubated in BHI broth for $4 \mathrm{~h}$, i.e., isolates were grown to the exponential phase at $37^{\circ} \mathrm{C}$. Then, the cultures were incubated in the presence of nisin-biogel at $1 / 2 \mathrm{MIC}(($ nisin $)=11.25 \mu \mathrm{g} / \mathrm{mL}), 1 / 4 \mathrm{MIC}$ $(($ nisin $)=5.625 \mu \mathrm{g} / \mathrm{mL})$ and $1 / 8 \mathrm{MIC}(($ nisin $)=2.8175 \mu \mathrm{g} / \mathrm{mL})$, and clindamycin at $1 / 2 \mathrm{MIC}$ $(($ clindamycin $)=0.0165 \mu \mathrm{g} / \mathrm{mL})$ for $18 \mathrm{~h}$ at $37^{\circ} \mathrm{C}$ with shaking. After incubation, bacte- 
rial suspensions were centrifuged at $1500 \times g \mathrm{rpm}$ for $10 \mathrm{~min}$ at $4{ }^{\circ} \mathrm{C}$, and supernatant were used to determine SpA level using the SpA ELISA Kit (Abcam, Cambridge, UK), as recommended by the manufacturer. Samples and standards were added to the 96-well plate, the assay was performed and absorvance values at $450 \mathrm{~nm}$ determined, as these values are directly proportional to the level of protein $\mathrm{A}$ in the sample. The results correspond to the ratios of the amount of $\mathrm{SpA}(\mathrm{pg} / \mathrm{mL})$ in the bacterial supernatants incubated with clindamycin or nisin-biogel and the mean amount of $\mathrm{SpA}(\mathrm{pg} / \mathrm{mL})$ in the bacterial supernatants incubated without antimicrobials and are expressed as percentages.

\subsection{Statistical Analysis}

Statistical analysis was carried out using Microsoft Excel $2016^{\circledR}$. Quantitative variables are expressed as mean values \pm standard deviation. Comparisons between treatments and control were performed using two-tailed Student's $t$-tests. A confidence interval of $95 \%$ was considered, and $p$-values $<0.05$ indicate statistical significance.

\section{Conclusions}

S. aureus produces a wide variety of virulence factors, such as adherence and colonization molecules, exotoxins, and enzymes, and forms biofilms, which contribute to its ability to colonize host tissues and cause disease, making it difficult to control staphylococcal infections. The effect of antimicrobial agents on these virulence factors' expression has become a major focal point in the study of new antimicrobial alternatives. The present results demonstrated that nisin-biogel at subinhibitory levels affects the growth of $S$. aureus in a strain-dependent and dose-dependent manner, as well as the production of several virulence factors, including coagulase, protein $\mathrm{A}$, and biofilm. The expression of some virulence-related genes, such as agrI, atl and $\operatorname{clf} A$, were found to be repressed by nisin-biogel at sub-MICs, whereas the transcription levels of $s p A, c o a, i c a A$ and icaD were increased. Results highlight the importance of accessing the effects of nisin-biogel sub-MICs at different levels, providing an in vitro basis to understand what happens in vivo throughout the treatment of a DFI, and emphasizes how critical it is to establish the correct dosage of antimicrobials to be applied in clinical practice.

Supplementary Materials: The following are available online at https:/ /www.mdpi.com/article/10 .3390 /antibiotics10121501/s1, Table S1: Primers used in RT-qPCR protocols using 7300 Real Time PCR System for accessing virulence gene expression; Table S2: Effects of nisin-biogel at 1/2 MIC, 1/4 MIC and 1/8 MIC and clindamycin at 1/2 MIC on agrI, spA, atl, clfA, coa, icaA and icaD mRNA expression for the isolates A 5.2, A 6.3, B 1.1, B 14.2, Z 1.1 and Z 5.2. Results are expressed as n-fold differences in 'gene under study/gyrB' ratio in the presence of the different conditions described above relative to 'gene under study/gyrB' ration in the growth control (no antimicrobial). Values are present as mean values $\pm \mathrm{SD}$ (two repeated different experiments), except for the $c l f a / g y r B$ fold change for the isolate Z 5.2, since only one assay was performed. Asterisks indicate statistically significant differences between treatments and between treatments and control for each clinical isolate $\left(^{*}=p<0.05 ;{ }^{* *}=p<0.01 ;{ }^{* * *}=p<0.001\right.$, compared with the results of the corresponding control); Table S3: Effects of nisin-biogel at 1/2 MIC, $1 / 4$ MIC and 1/8 MIC and clindamycin at 1/2 MIC on biofilm formation by the isolates A 5.2, A 6.3, B 1.1, B 14.2, Z 1.1 and Z 5.2. Values are present as mean values $\pm \mathrm{SD}$ (three repeated different experiments). ${ }^{*}=p<0.05 ;{ }^{* *}=p<0.01$; ${ }^{* * *}=p<0.001$, compared with the results of the corresponding control; Table S4: Effects of nisin-biogel at 1/2 MIC, 1/4 MIC and $1 / 8 \mathrm{MIC}$ and clindamycin at $1 / 2 \mathrm{MIC}$ on coagulase production by the isolates A 5.2, A 6.3, B 1.1, B 14.2, Z 1.1 and Z 5.2 after 24 h of growth under the different conditions tested. Coagulation ability was measured every hour for $4 \mathrm{~h}$ of incubation, and after $24 \mathrm{~h}$ of incubation. -: no evidence of fibrin formation; $1+$ : small unorganized clots; $2+$ : small organized clots; $3+$ : large organized clots; 4+: entire content of tube coagulates and is not displaced when tube is inverted; Table S5: Effects of nisin-biogel at $1 / 2 \mathrm{MIC}, 1 / 4 \mathrm{MIC}$ and $1 / 8 \mathrm{MIC}$ and clindamycin at $1 / 2 \mathrm{MIC}$ on coagulase production by the isolates A 5.2, A 6.3, B 1.1, B 14.2, Z 1.1 and Z 5.2 after $4 \mathrm{~h}$ of growth under the different conditions tested. Coagulation ability was measured every hour for $4 \mathrm{~h}$ of incubation, and after $24 \mathrm{~h}$ of incubation. -: no evidence of fibrin formation; $1+$ : small unorganized clots; $2+$ : small organized 
clots; 3+: large organized clots; 4+: entire content of tube coagulates and is not displaced when tube is inverted; Table S6: Effects of nisin-biogel at 1/2 MIC, 1/4 MIC and 1/8 MIC and clindamycin at 1/2 MIC on protein A release by S. aureus DFI isolates A 5.2, A 6.3, B 1.1, B 14.2, Z 1.1 and Z 5.2 after $18 \mathrm{~h}$ of growth under the different conditions tested. The results are the racios of the amount of SpA $(\mathrm{pg} / \mathrm{mL})$ in the bacterial supernatants incubated with nisin-biogel or clindamycin to the amount of SpA $(\mathrm{pg} / \mathrm{mL})$ in the bacterial supernatants incubated without antimicrobials and are expressed as percentages.

Author Contributions: Conceptualization, C.J., R.S. and M.O.; Methodology, C.J., R.S. and M.O.; Validation, E.C., M.G., L.T. and M.O.; Investigation, C.J.; Data curation, C.J.; Writing-original draft preparation, C.J.; Writing-review and editing, R.S., E.C., M.G., L.T. and M.O.; Supervision, M.O.; Project administration, L.T. and M.O.; Funding acquisition, L.T. and M.O. All authors have read and agreed to the published version of the manuscript.

Funding: This research was funded by Foundation for Science and Technology, project PTDC/SAUINF/28466/2017-Polyphasic validation of antimicrobial peptides as alternative treatment for diabetic foot infections). The authors would also like to recognize the Foundation of Science and Technology for the PhD fellowship SFRH/BD/131384/2017 (Eva Cunha) and to the University of Lisbon for the PhD fellowship C10571K (Miguel L. Grilo).

Institutional Review Board Statement: Not applicable.

Informed Consent Statement: Not applicable.

Data Availability Statement: The data presented in this study are available in the article or Supplementary Materials.

Conflicts of Interest: The authors declare no conflict of interest.

\section{References}

1. IDF Diabetes Atlas—9th Edition. Available online: https:/ / diabetesatlas.org/ (accessed on 27 November 2021).

2. Armstrong, D.G.; Boulton, A.J.M.; Bus, S.A. Diabetic Foot Ulcers and Their Recurrence. N. Engl. J. Med. 2017, 376, 2367-2375. [CrossRef] [PubMed]

3. Noor, S.; Khan, R.U.; Ahmad, J. Understanding Diabetic Foot Infection and Its Management. Diabetes Metab. Syndr. Clin. Res. Rev. 2017, 11, 149-156. [CrossRef] [PubMed]

4. Wang, B.; Muir, T.W. Regulation of Virulence in Staphylococcus aureus: Molecular Mechanisms and Remaining Puzzles. Cell Chem. Biol. 2016, 23, 214-224. [CrossRef] [PubMed]

5. Periasamy, S.; Joo, H.S.; Duong, A.C.; Bach, T.H.L.; Tan, V.Y.; Chatterjee, S.S.; Cheung, G.Y.C.; Otto, M. How Staphylococcus aureus Biofilms Develop Their Characteristic Structure. Proc. Natl. Acad. Sci. USA 2012, 109, 1281-1286. [CrossRef] [PubMed]

6. Biswas, R.; Voggu, L.; Simon, U.K.; Hentschel, P.; Thumm, G.; Götz, F. Activity of the Major Staphylococcal Autolysin Atl. FEMS Microbiol. Lett. 2006, 259, 260-268. [CrossRef]

7. Porayath, C.; Suresh, M.K.; Biswas, R.; Nair, B.G.; Mishra, N.; Pal, S. Autolysin Mediated Adherence of Staphylococcus aureus with Fibronectin, Gelatin and Heparin. Int. J. Biol. Macromol. 2018, 110, 179-184. [CrossRef]

8. Singh, V.K. High Level Expression and Purification of Atl, the Major Autolytic Protein of Staphylococcus aureus. Int. J. Microbiol. 2014, 2014, 1-7.

9. Reffuveille, F.; Josse, J.; Vallé, Q.; Mongaret, C.; Gangloff, S.C. Staphylococcus aureus Biofilms and Their Impact on the Medical Field; InTech: London, UK, 2017; Volume 11, p. 187.

10. Dickschat, J.S. Quorum Sensing and Bacterial Biofilms. Nat. Prod. Rep. 2010, 27, 343-369. [CrossRef] [PubMed]

11. Maira-Litrán, T.; Kropec, A.; Abeygunawardana, C.; Joyce, J.; Mark, G.; Goldmann, D.A.; Pier, G.B. Immunochemical Properties of the Staphylococcal Poly-N-Acetylglucosamine Surface Polysaccharide. Infect. Immun. 2002, 70, 4433-4440. [CrossRef]

12. Otto, M. Staphylococcal Biofilms. In Gram-Positive Pathogens; ASM Press: Washington, DC, USA, 2019 ; pp. 699-711.

13. O'Gara, J.P. Ica and beyond: Biofilm Mechanisms and Regulation in Staphylococcus epidermidis and Staphylococcus aureus. FEMS Microbiol. Lett. 2007, 270, 179-188. [CrossRef]

14. Huntzinger, E.; Boisset, S.; Saveanu, C.; Benito, Y.; Geissmann, T.; Namane, A.; Lina, G.; Etienne, J.; Ehresmann, B.; Ehresmann, C.; et al. Staphylococcus aureus RNAIII and the Endoribonuclease III Coordinately Regulate Spa Gene Expression. EMBO J. 2005, 24, 824-835. [CrossRef]

15. Kong, K.F.; Vuong, C.; Otto, M. Staphylococcus Quorum Sensing in Biofilm Formation and Infection. Int. J. Med. Microbiol. 2006, 133-139. [CrossRef]

16. Chastain, C.A.; Klopfenstein, N.; Serezani, C.H.; Aronoff, D.M. A Clinical Review of Diabetic Foot Infections. Clin. Podiatr. Med. Surg. 2019, 36, 381-395. [CrossRef] [PubMed]

17. Field, D.; O'Connor, R.; Cotter, P.D.; Ross, R.P.; Hill, C. In Vitro Activities of Nisin and Nisin Derivatives Alone and In Combination with Antibiotics against Staphylococcus Biofilms. Front. Microbiol. 2016, 7, 508. [CrossRef] 
18. Grigoropoulou, P.; Eleftheriadou, I.; Jude, E.B.; Tentolouris, N. Diabetic Foot Infections: An Update in Diagnosis and Management. Curr. Diabetes Rep. 2017, 17, 3. [CrossRef] [PubMed]

19. Han, D.; Sherman, S.; Filocamo, S.; Steckl, A.J. Long-Term Antimicrobial Effect of Nisin Released from Electrospun Triaxial Fiber Membranes. Acta Biomater. 2017, 53, 242-249. [CrossRef]

20. Peterson, E.; Kaur, P. Antibiotic Resistance Mechanisms in Bacteria: Relationships between Resistance Determinants of Antibiotic Producers, Environmental Bacteria, and Clinical Pathogens. Front. Microbiol. 2018, 9, 2928. [CrossRef] [PubMed]

21. Perez, R.; Perez, M.T.; Elegado, F. Bacteriocins from Lactic Acid Bacteria: A Review of Biosynthesis, Mode of Action, Fermentative Production, Uses, and Prospects. Int. J. Philipp. Sci. Technol. 2015, 8, 61-67. [CrossRef]

22. Delves-Broughton, J.; Blackburn, P.; Evans, R.J.; Hugenholtz, J. Applications of the Bacteriocin, Nisin. Antonie Van Leeuwenhoek 1996, 69, 193-202. [CrossRef]

23. Punyauppa-Path, S.; Phumkhachorn, P. Nisin: Production and Mechanism of Antimicrobial Action. Int. J. Curr. Res. Rev. 2015, 7, 47-53.

24. Mirhosseini, H.; Amid, B.T. A Review Study on Chemical Composition and Molecular Structure of Newly Plant Gum Exudates and Seed Gums. Food Res. Int. 2012, 46, 387-398. [CrossRef]

25. Narsaiah, K.; Jha, S.N.; Wilson, R.A.; Mandge, H.M.; Manikantan, M.R. Optimizing Microencapsulation of Nisin with Sodium Alginate and Guar Gum. J. Food Sci. Technol. 2014, 51, 4054-4059. [CrossRef] [PubMed]

26. Prabaharan, M. Prospective of Guar Gum and Its Derivatives as Controlled Drug Delivery Systems. Int. J. Biol. Macromol. 2011, 49, 117-124. [CrossRef]

27. Santos, R.; Gomes, D.; Macedo, H.; Barros, D.; Tibério, C.; Veiga, A.S.; Tavares, L.; Castanho, M.; Oliveira, M. Guar Gum as a New Antimicrobial Peptide Delivery System against Diabetic Foot Ulcers Staphylococcus aureus Isolates. J. Med. Microbiol. 2016, 65, 1092-1099. [CrossRef] [PubMed]

28. Santos, R.; Ruza, D.; Cunha, E.; Tavares, L.; Oliveira, M. Diabetic Foot Infections: Application of a Nisin-Biogel to Complement the Activity of Conventional Antibiotics and Antiseptics against Staphylococcus aureus Biofilms. PLoS ONE 2019, 14, e0220000. [CrossRef]

29. Gomes, D.; Santos, R.; Soares, R.S.; Reis, S.; Carvalho, S.; Rego, P.; Peleteiro, M.C.; Tavares, L.; Oliveira, M. Pexiganan in Combination with Nisin to Control Polymicrobial Diabetic Foot Infections. Antibiotics 2020, 9, 128. [CrossRef]

30. Soares, R.S.; Santos, R.; Cunha, E.; Tavares, L.; Trindade, A.; Oliveira, M. Influence of Storage on the Antimicrobial and Cytotoxic Activities of a Nisin-biogel with Potential to be Applied to Diabetic Foot Infections Treatment. Antibiotics 2020, 9, 781. [CrossRef] [PubMed]

31. Andersson, D.I.; Hughes, D. Microbiological Effects of Sublethal Levels of Antibiotics. Nat. Rev. Microbiol. 2014, 12, 465-478. [CrossRef]

32. Li, J.; Xie, S.; Ahmed, S.; Wang, F.; Gu, Y.; Zhang, C.; Chai, X.; Wu, Y.; Cai, J.; Cheng, G. Antimicrobial Activity and Resistance: Influencing Factors. Front. Pharmacol. 2017, 8, 364. [CrossRef]

33. Otto, M.P.; Martin, E.; Badiou, C.; Lebrun, S.; Bes, M.; Vandenesch, F.; Etienne, J.; Lina, G.; Dumitrescu, O. Effects of Subinhibitory Concentrations of Antibiotics Factor Expression by Community-Acquired Methicillin-Staphylococcus aureus. J. Antimicrob. Chemother. 2013, 68, 1524-1532. [CrossRef] [PubMed]

34. Davies, J.; Spiegelman, G.B.; Yim, G. The World of Subinhibitory Antibiotic Concentrations. Curr. Opin. Microbiol. 2006, 9, 445-453 [CrossRef]

35. Herbert, S.; Barry, P.; Novick, R.P. Subinhibitory Clindamycin Differentially Inhibits Transcription of Exoprotein Genes in Staphylococcus aureus. Infect. Immun. 2001, 69, 2996-3003. [CrossRef] [PubMed]

36. Schilcher, K.; Andreoni, F.; Dengler Haunreiter, V.; Seidl, K.; Hasse, B.; Zinkernagel, A.S. Modulation of Staphylococcus aureus Biofilm Matrix by Subinhibitory Concentrations of Clindamycin. Antimicrob. Agents Chemother. 2016, 60, 5957-5967. [CrossRef] [PubMed]

37. IDF Europe Members-Portugal. Available online: https://idf.org/our-network/regions-members/europe/members/153portugal.html (accessed on 27 November 2021).

38. Heravi, F.S.; Zakrzewski, M.; Vickery, K.; Armstrong, D.G.; Hu, H. Bacterial Diversity of Diabetic Foot Ulcers: Current Status and Future Prospectives. J. Clin. Med. 2019, 8, 1935. [CrossRef] [PubMed]

39. Reeks, B.Y.; Champlin, F.R.; Paulsen, D.B.; Scruggs, D.W.; Lawrence, M.L. Effects of Sub-Minimum Inhibitory Concentration Antibiotic Levels and Temperature on Growth Kinetics and Outer Membrane Protein Expression in Mannheimia haemolytica and Heamophilus somnus. Can. J. Vet. Res. 2005, 69, 1-10.

40. Zhanel, G.G.; Hoban, D.J.; Harding, G.K. Subinhibitory Antimicrobial Concentrations: A Review of In Vitro and In Vivo Data. Can. J. Infect. Dis. 1992, 3, 193-201. [CrossRef]

41. Pratten, J.; Foster, S.J.; Chan, P.F.; Wilson, M.; Nair, S.P. Staphylococcus aureus Accessory Regulators: Expression within Biofilms and Effect on Adhesion. Microbes Infect. 2001, 3, 633-637. [CrossRef]

42. Liu, D.; Li, Z.; Wang, G.; Li, T.; Zhang, L.; Tang, P. Virulence Analysis of Staphylococcus aureus in a Rabbit Model of Infected Full-Thickness Wound under Negative Pressure Wound Therapy. Int. J. Gen. Mol. Microbiol. 2018, 111, 161-170. [CrossRef]

43. Mottola, C.; Mendes, J.J.; Cristino, J.M.; Cavaco-Silva, P.; Tavares, L.; Oliveira, M. Polymicrobial Biofilms by Diabetic Foot Clinical Isolates. Folia Microbiol. 2016, 61, 35-43. [CrossRef] [PubMed] 
44. Peng, H.L.; Novick, R.P.; Kreiswirth, B.; Kornblum, J.; Schlievert, P. Cloning, Characterization, and Sequencing of an Accessory Gene Regulator (agr) in Staphylococcus aureus. J. Bacteriol. 1988, 170, 4365-4372. [CrossRef]

45. Gómez, M.I.; O'Seaghdha, M.; Magargee, M.; Foster, T.J.; Prince, A.S. Staphylococcus aureus Protein A Activates TNFR1 Signaling through Conserved IgG Binding Domains. J. Biol. Chem. 2006, 281, 20190-20196. [CrossRef]

46. Yanagihara, K.; Tashiro, M.; Fukuda, Y.; Ohno, H.; Higashiyama, Y.; Miyazaki, Y.; Hirakata, Y.; Tomono, K.; Mizuta, Y.; Tsukamoto, K.; et al. Effects of Short Interfering RNA against Methicillin-Resistant Staphylococcus aureus Coagulase In Vitro and In Vivo. J. Antimicrob. Chemother. 2006, 57, 122-126. [CrossRef]

47. Vandenesch, F.; Kornblum, J.; Novick, R.P. A Temporal Signal, Independent of Agr, Is Required for Hla but Not Spa Transcription in Staphylococcus aureus. J. Bacteriol. 1991, 173, 6313-6320. [CrossRef]

48. Lebeau, C.; Vandenesch, F.; Greenland, T.; Novick, R.P.; Etienne, J. Coagulase Expression in Staphylococcus aureus Is Positively and Negatively Modulated by an agr-Dependent Mechanism. J. Bacteriol. 1994, 176, 5534-5536. [CrossRef] [PubMed]

49. Farnsworth, C.W.; Schott, E.M.; Jensen, S.E.; Zukoski, J.; Benvie, A.M.; Refaai, M.A.; Kates, S.L.; Schwarz, E.M.; Zuscik, M.J.; Gill, S.R.; et al. Adaptive Upregulation of Clumping Factor A (clfA) by Staphylococcus aureus in the Obese, Type 2 Diabetic Host Mediates Increased Virulence. Infect. Immun. 2017, 85, e01005-16. [CrossRef] [PubMed]

50. Josefsson, E.; Kubica, M.; Mydel, P.; Potempa, J.; Tarkowski, A. In Vivo Sortase A and Clumping Factor A MRNA Expression during Staphylococcus aureus Infection. Microb. Pathog. 2008, 44, 103-110. [CrossRef] [PubMed]

51. Pasztor, L.; Ziebandt, A.K.; Nega, M.; Schlag, M.; Haase, S.; Franz-Wachtel, M.; Madlung, J.; Nordheim, A.; Heinrichs, D.E.; Götz, F. Staphylococcal Major Autolysin (Atl) Is Involved in Excretion of Cytoplasmic Proteins. J. Biol. Chem. 2010, 285, 36794-36803. [CrossRef]

52. Oshida, T.; Takano, M.; Sugai, M.; Suginaka, H.; Matsushita, T. Expression Analysis of the Autolysin Gene (atl) of Staphylococcus aureus. Microbiol. Immunol. 1998, 42, 655-659. [CrossRef]

53. Atshan, S.S.; Shamsudin, M.N.; Karunanidhi, A.; van Belkum, A.; Lung, L.T.T.; Sekawi, Z.; Nathan, J.J.; Ling, K.H.; Seng, J.S.C.; Ali, A.M.; et al. Quantitative PCR Analysis of Genes Expressed during Biofilm Development of Methicillin Resistant Staphylococcus aureus (MRSA). Infect. Genet. Evol. 2013, 18, 106-112. [CrossRef] [PubMed]

54. Patel, J.D.; Colton, E.; Ebert, M.; Anderson, J.M. Gene Expression during S. epidermidis Biofilm Formation on Biomaterials. J. Biomed. Mater. Res. 2012, 100, 2863-2869. [CrossRef]

55. Smieja, M. Current Indications for the Use of Clindamycin: A Critical Review. Can. J. Infect. Dis. 1998, 9, 22-28. [CrossRef]

56. Zhao, X.; Meng, R.; Shi, C.; Liu, Z.; Huang, Y.; Zhao, Z.; Guo, N.; Yu, L. Analysis of the Gene Expression Profile of Staphylococcus aureus Treated with Nisin. Food Control 2016, 59, 499-506. [CrossRef]

57. Malone, M.; Bjarnsholt, T.; McBain, A.J.; James, G.A.; Stoodley, P.; Leaper, D.; Tachi, M.; Schultz, G.; Swanson, T.; Wolcott, R.D. The Prevalence of Biofilms in Chronic Wounds: A Systematic Review and Meta-Analysis of Published Data. J. Wound Care 2017, 26, 20-25. [CrossRef] [PubMed]

58. Andre, C.; de Jesus Pimentel-Filho, N.; de Almeida Costa, P.M.; Vanetti, M.C.D. Changes in the Composition and Architecture of Staphylococcal Biofilm by Nisin. Braz. J. Microbiol. 2019, 50, 1083-1090. [CrossRef]

59. Kaplan, J.B. Antibiotic-Induced Biofilm Formation. Int. J. Artif. Organs 2011, 34, 737-751. [CrossRef] [PubMed]

60. Angelopoulou, A.; Field, D.; Pérez-Ibarreche, M.; Warda, A.K.; Hill, C.; Ross, R.P. Vancomycin and Nisin A Are Effective against Biofilms of Multi-Drug Resistant Staphylococcus aureus Isolates from Human Milk. PLoS ONE 2020, 15, e0233284. [CrossRef]

61. Majidpour, A.; Fathizadeh, S.; Afshar, M.; Rahbar, M.; Boustanshenas, M.; Heidarzadeh, M.; Arbabi, L.; Soleymanzadeh Moghadam, S. Dose-Dependent Effects of Common Antibiotics Used to Treat Staphylococcus aureus on Biofilm Formation. Iran. J. Pathol. 2017, 12, 362-370. [CrossRef]

62. Hodille, E.; Rose, W.; Diep, B.A.; Goutelle, S.; Lina, G.; Dumitrescu, O. The Role of Antibiotics in Modulating Virulence in Staphylococcus aureus. Clin. Microbiol. Rev. 2017, 30, 887-917. [CrossRef]

63. McAdow, M.; Missiakas, D.M.; Schneewind, O. Staphylococcus aureus Secretes Coagulase and von Willebrand Factor Binding Protein to Modify the Coagulation Casca de and Establish Host Infections. J. Innate Immun. 2012, 4, 141-148. [CrossRef]

64. Blickwede, M.; Wolz, C.; Valentin-Weigand, P.; Schwarz, S. Influence of Clindamycin on the Stability of Coa and FnbB Transcripts and Adherence Properties of Staphylococcus aureus Newman. FEMS Microbiol. Lett. 2005, 252, 73-78. [CrossRef]

65. Mendes, J.J.; Marques-Costa, A.; Vilela, C.; Neves, J.; Candeias, N.; Cavaco-Silva, P.; Melo-Cristino, J. Clinical and Bacteriological Survey of Diabetic Foot Infections in Lisbon. Diabetes Res. Clin. Pract. 2012, 95, 153-161. [CrossRef] [PubMed]

66. Mottola, C.; Semedo-Lemsaddek, T.; Mendes, J.J.; Melo-Cristino, J.; Tavares, L.; Cavaco-Silva, P.; Oliveira, M. Molecular Typing, Virulence Traits and Antimicrobial Resistance of Diabetic Foot Staphylococci. J. Biomed. Sci. 2016, 23, 33. [CrossRef]

67. Mottola, C.; Matias, C.S.; Mendes, J.J.; Melo-Cristino, J.; Tavares, L.; Cavaco-Silva, P.; Oliveira, M. Susceptibility Patterns of Staphylococcus aureus Biofilms in Diabetic Foot Infections. BMC Microbiol. 2016, 16, 119. [CrossRef]

68. Kearns, A.M.; Seiders, R.R.; Wheeler, J.; Freeman, R.; Steward, M. Rapid Detection of Methicillin-Resistant Staphylococci by Multiplex PCR. J. Hosp. Infect. 1999, 43, 33-37. [CrossRef] [PubMed]

69. Sperber, W.H.; Tatini, S.R. Interpretation of the Tube Coagulase Test for Identification of Staphylococcus aureus. Appl. Microbiol. 1975, 29, 502-505. [CrossRef] [PubMed] 